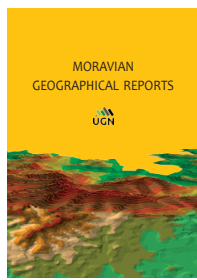

MORAVIAN GEOGRAPHICAL REPORTS

\title{
On the spatial differentiation of energy transitions: Exploring determinants of uneven wind energy developments in the Czech Republic
}

\author{
Bohumil FRANTÁL a *, Eva NOVÁKOVÁa ${ }^{a}$
}

\begin{abstract}
Wind energy research is dominated by studies of local acceptance (or not) of wind farms and comparative studies at a national level. Research on the spatial differentiation of wind energy developments at the regional level is still insufficient, however. This study provides new empirical evidence for the extent to which regional differences in the deployment of wind energy are related to specific environmental and socioeconomic factors, by a statistical analysis of data for districts in the Czech Republic. Unlike previous studies, we found that the installed capacity of wind energy cannot be well predicted by wind potential, land area and population density in an area. In the Czech Republic, wind farms more likely have been implemented in more urbanised, environmentally deprived coal-mining areas that are affected by economic depression. It seems that in environmentally deprived areas, wind energy is more positively accepted as an alternative source to coal, and the economic motivation (financial benefits for municipalities) can have a greater effect on local acceptance, while public opposition is less efficient due to lower social capital and involvement in political matters. Based on these results, some implications for the planning and spatial targeting of new wind farms are discussed.
\end{abstract}

Keywords: wind energy; spatial differentiation; uneven development; energy geography; Czech Republic

Article history: Received 15 March 2019, Accepted 13 June 2019, Published 30 June 2019

\section{Introduction}

Geographers can significantly contribute to understanding sustainability transitions by paying attention to particular settings (places), spatial configurations and the dynamics of the networks within which the transitions are embedded (Hansen and Coenen, 2015). Generally, the ongoing lowcarbon energy transition, particularly the development of renewable energy production systems, can be considered a process of the diffusion of innovations or the process of spreading new ideas transferred into the forms of technologies, products, processes and organisations in space and time (Wolsink, 2012). The diffusions of innovations are in principle spatially uneven at all spatial levels (Hägerstrand, 1968). The differences in the deployment of renewable energy facilities cannot be explained simply by physical-geographic and infrastructural conditions of specific areas (i.e. the available land, wind resources, nature and landscape protection limits, transmission grid capacity, etc.), but also (and perhaps most importantly) by political-institutional and socio-economic factors which affect the perceptions, motivations and acceptance of policy makers and stakeholders entering the "games" in planning and decision-making processes (Aitken, 2010; Fournis and Fortin, 2017; Rand and Hoen, 2017).

Comparative studies analysing political-institutional contexts, different outcomes and in-time diffusion patterns of wind energy development at the national level are numerous. As well, studies focusing on the factors affecting perceptions and acceptance of wind turbines by local communities are quite common. Research focusing on differences in wind energy deployment at the regional level, however, is still inadequate to confirm or reject hypotheses about the role of environmental and socio-economic characteristics of areas in accounting for such differences (see the overview of literature in Section 2). Balta-Ozkan and colleagues (2015) pointed out that the nature of the lowcarbon energy transition and its socio-economic outcomes at different scales have not been fully understood to date because the focus of most energy research and analysis is at the national and/or the local level.

\footnotetext{
${ }^{a}$ Department of Environmental Geography, Institute of Geonics, The Czech Academy of Sciences, Brno, Czech Republic (*corresponding author: B. Frantál, e-mail: bohumil.frantal@ugn.cas.cz)
} 
The aim of this paper is to contribute to existing research by analysing the extent to which regional differences in the deployment of wind energy are related to geographical, environmental, and socio-economic factors, by analysing selected statistical data (some 35 variables) for districts in the Czech Republic - a country with one of the lowest rates of the deployment of wind energy potential in Europe. In addition to extending theoretical knowledge, the results have implications for wind energy developers: where to focus their interest and energy in promoting new projects; and for politicians: where to encourage and stimulate new investments by supportive land-use policy frameworks.

\section{Spatial differentiation and the uneven development of renewables: Literature overview}

Geographers have long been interested in the study of the diffusion of innovations (Howells and Bessant, 2012; Diebolt et al., 2016). Changing energy production systems with a distributed generation of renewables have brought new challenges to Geography as a discipline, and gave rise to new "Energy Geographies" (Frantál, Pasqualetti and van der Horst, 2014; Calvert, 2016). One of the most important geographical concepts applied in energy research is spatial differentiation or the production of geographical difference (Bridge et al., 2013). Since the capacity to take up different renewable energy technologies is related to geographical conditions and prevailing conceptions of landscape quality, the locations, landscapes and territorialisations associated with energy transitions generate new patterns of uneven development amongst others (cf. Bridge et al., 2013, p. 337).

A growing number of studies across Europe has confirmed the presence of spatial patterns in the uneven adoption of renewable energy technologies. The most recent studies have focused on the adoption of small-scale (domestic) technologies at the level of households (Balta-Ozkan et al., 2015; Dharshing, 2017; Heiskanen and Matschoss, 2017; Palm and Tengvard, 2011, etc.). Schaffer and Brun (2015) suggest that factors such as house density, homeownership, percapita income and neighbourhood effects are equally or even more important than solar radiation for understanding the uneven diffusion of PV installations in Germany. In the UK, Balta-Ozkan and colleagues (2016) found that the diffusion of PVs is determined by density of buildings, pollution levels, education level and housing types. Several studies then confirmed the effect of social spill-overs and clustering of adoptions of residential PV installations (e.g. Graziano and Gillingham, 2015; Bollinger and Gillingham, 2012).

As concerns wind energy development, researchers have examined broadly the diffusion dynamics and differences in wind energy deployment outcomes in different countries (e.g. Buen, 2006; Breukers and Wolsink, 2007; Petterson et al., 2010; Davies and Diaz-Rainey, 2011; Dalla Valle and Furlan, 2011; Bauwens et al., 2016). A widely-cited study by Toke et al. (2008) pointed out the role of political-institutional factors, such as political-cultural traditions, energy policies, land-use planning systems, landscape protection norms and organisations, financial support mechanisms and ownership patterns. Most studies have been concerned with the local acceptance of wind energy projects (e.g. Jobert et al., 2007; Janhunen et al., 2014; Fast and Mabee, 2015; Firestone et al., 2015; Rand and Hoen, 2017). Research to date demonstrates the complex and multi-faceted dimensions of 'acceptance', as factors range from personal characteristics, perceived side-effects, process-related variables, and technical and geographical issues (Langer et al., 2016). Among other findings, the results suggest that lower levels of local resistance is found in areas of low landscape value, in polluted areas with heavy industries, areas with low political efficacy, and in areas with a low concentration of secondhome owners escaping from the city for a 'rural idyll' (see e.g. van der Horst, 2007, Frantál and Kunc, 2011).

The research literature dealing with regional differences in wind energy development is scarce, however, involving only a few countries - basically those with the largest installed capacities, such as China, USA, Germany, India, Canada and Sweden. Ferguson-Martin and Hill (2011) and Rao and Kishore (2009) followed the approach of Toke et al. (2008) and examined the impact of political-institutional factors on the uneven development of wind energy across provinces in Canada and India. Various studies, largely quantitative in nature, that have explored the relationships between wind energy development and area characteristics are summarised in Table 1.

The two earliest studies from Europe (Tab. 1) investigated differences between areas with accepted wind farms and rejected wind farms - in England and the Czech Republic (van der Horst and Toke, 2010; Frantál and Kunc, 2010, respectively). The areas that were the most likely to refuse planning permission for wind farms in England are characterised by a local population which has a higher life expectancy, a higher likelihood of voting, and a lower exposure to crime. In the Czech Republic, wind farms were accepted to a greater degree in small municipalities with low populations (up to 500 inhabitants) and located in more polluted areas. Limitations of these studies are that they did not account for projects in the whole country but chose selected cases (77 projects in England; 118 projects in the Czech Republic), and only used a binary dependent variable (accepted or rejected).

Mann et al. (2012) reported that wind energy development in Iowa is negatively related to population density within a $50 \mathrm{~km}$ radius of the development and distances from transmission lines and highways, but positively related to the amount of cropland and population density within a $200 \mathrm{~km}$ radius. Staid and Guikema (2013) reported similar results, pointing out that wind resources, the available share of land, and the amount of cropland are the strongest predictors of wind energy development in the US states. Ek et al. (2013) analysed differences in the installed wind capacity in Swedish municipalities in two time periods (before and after 2006). In the early period, the projects were implemented more likely in large and sparsely populated municipalities with a positive population trend, and - in the later period - the municipalities with existing wind power plants and good wind resources were more likely to continue to exploit wind energy.

A comparative study by Lauf et al. (2018) found that regional variations in wind power deployment in Sweden and Germany, to a significant extent, can be attributed to land-use policies, not least in the form of priority areas and the designation of restricted areas. This study also confirmed a positive correlation of wind capacity with the land area and a negative correlation with population density. Another study from Germany (Goetzke and Rave, 2016) verified that the wind energy capacity is higher in larger counties and in counties with suitable land with fewer hills and mountains. They also found a significant correlation between Green Party votes and wind energy development, which seems to 


\begin{tabular}{llll}
\hline \multicolumn{1}{c}{ Authors } & Country / level of analysis & \multicolumn{1}{c}{ Method } & \multicolumn{1}{c}{ Independent variables tested } \\
\hline $\begin{array}{l}\text { van der Horst, Toke } \\
\text { (2010) }\end{array}$ & $\begin{array}{l}\text { England/Lower layer Super } \\
\text { Output Areas }\end{array}$ & $\begin{array}{l}\text { Mann-Whitney test, } \\
\text { Univariate regressions }\end{array}$ & $\begin{array}{l}\text { More than a hundred variables related to education, } \\
\text { health, demography, employment and housing }\end{array}$ \\
Frantál, Kunc (2010) & Czech Republic/Municipalities & Bivariate correlations & $\begin{array}{l}\text { Proximity to protected landscape area, natural } \\
\text { attractiveness, tourism potential, recreational areas } \\
\text { ratio, air pollution, municipal budget, population, } \\
\text { and ageing index }\end{array}$
\end{tabular}

Mann et al. (2012)

Iowa, US/One square kilometer cells

Logistic regression model

Eight different regression models

Cragg specification of the Tobit model

Poisson regression model

Partial adjustment model

Tobit regression model

Germany \& Sweden / Districts $\&$ Municipalities

Lauf et al. (2018)
Wind potential, distances to power line, highway, airport and railroad, land cover types, conservation area, population density, education, and household value

Wind potential, land area, amount of cropland, median income, electricity rate, renewable portfolio standards, tax, rebate, loan and other incentives, and the share of Democrats in the State government

Land area, population density, population trend, unemployment, environmental index, and classification according to national interest for wind energy

Wind potential, land area, share of suitable area, relief measure, lagged property value, per capita gross regional product, unemployment, green party votes, and orientation of state government

Wind potential, land area, population density, local economy indicators, transmission grid density, presence of other energy sources, tax and price policies

Wind potential, land area, share of protected areas and priority areas, population density, unemployment, participation of green party in state government, and state's installed capacity

Tab. 1: Summary of recent quantitative studies analysing regional differences in wind energy development Source: authors' compilation following annotated sources

be facilitated when the state government is left-of-center. A counterfactual analysis revealed, however, that the effect of votes significantly varied in different states. It rather seems that in states with less favourable geographical conditions, fewer additional wind farms would be built, even if the support for Green Party is high, and vice versa (cf. Goetzke and Rave, 2016). Xia and Song (2017) confirmed that wind energy development shows an agglomeration effect (i.e. existing installed capacity attracts new addition of capacity), while they found local economic indicators and transmission capacity insignificant for the location choice for wind farms in China.

To summarise this research, these studies have largely confirmed that geographical characteristics, such as wind resources, the availability of not restricted sparsely populated land, and access to infrastructure facilities, best predict wind energy development in an area. The hypothesis that regions characterised by economic decline will be more likely interested in attracting new investments in wind energy has not been fully confirmed. A significant correlation between unemployment and wind capacity growth was shown only in Germany. Lauf et al. (2018) question this relationship, however, by claiming that districts with high unemployment rates are not more likely to host wind investments, but in the presence of such investments they tend to experience higher capacity additions. The hypothesis about the relationship between votes for left-wing parties (particularly the Green Party) and their participation in regional governments has been supported only by Goetzke and Rave (2016); however, they point to considerable regional variations in the effect of these variables.

As Balta-Ozkan and Le Gallo (2017) emphasise, we cannot claim that the revealed relationships between environmental and socio-economic factors and the rate of adoption of renewable energy technologies are linear; rather, that our understanding of these interactions is still limited and should be further investigated.

We aim to contribute to the existing literature in two ways: First, we provide the first complex quantitative analysis ${ }^{1}$ of regional differences in the deployment of wind energy in post-socialist East-Central Europe, a region which is still characterised by some pecularities concerning the energy transition (a prevailing carbon lock-in, high public support for nuclear power, lack of trust and social justice in energy planning processes, etc. - see for example: Piria et al., 2014; Martinovský and Mareš, 2012; Suškevičs, et al., 2019); and - Second, we include in the analysis, among other variables, indicators of environmental deprivation (see e.g. Pearce et al., 2010; Richardson, 2013) that have been mostly neglected in previous regional studies.

\section{Geographical context of the study}

The current energy policy of the Czech Republic remains highly dependent on traditional resources. Overall, electricity generation is based primarily on thermal or

\footnotetext{
1 The study by Frantál and Kunc (2010) has been significantly limited by the sample of implemented wind energy projects and the lack of proper statistical data for municipalities (Local administrative units - LAU2)
} 
combined-cycle power plants burning brown coal [42\%], black coal [5\%], gas and other fuels [8\%], nuclear power plants [33\%], with a mix of renewable energy sources at a mere $12 \%$ (ERU, 2018). While the Czech Republic is among the EU leaders in the production of solar energy and biogas (particularly in agricultural AD plants), they are laggards in the implementation of wind energy (Roth et al., 2018). The realisable wind potential in the country (soberly estimated between 2,500-3,500 MW: see Hanslian et al., 2008; Chalupa and Hanslian, 2015) is far from being effectively utilised. At the end of 2018, the total installed capacity reached only $310 \mathrm{MW}$ and the spatial diffusion of implemented wind farms is characterised by marked regional differentiation (see Fig. 1).

The Czech Republic still has one of the highest levels of public support for nuclear energy in the EU, on the one hand, but distrustful and partly utilitarian attitudes towards renewables on the other (Frantál and Prousek, 2016; Frantál et al., 2017; Martinát et al., 2017). The public image of and political attitudes to renewables have been adversely affected by the unrestrained boom of the 'solar business' (due to a cheaper technology and overly-generous support schemes, the installed capacity of PVs increased from only 3 MW in 2008 to 2,000 MW in 2011, with most plants installed on agricultural land). Some (but few) 'bad-practice' examples of wind farms and biogas plants have been publicised, often presented in the media as common standards. As a result, the government subsequently destabilised the business environment by making retroactive changes in the form of a solar tax and, in 2014, practically cut off any support for new solar, biogas and wind installations.

Potential landscape impacts are definitely the bone of contention and a major limiting factor for further development of renewables in the Czech Republic. It is a small country with a wide variety of natural conditions and landscape structures, which make it quite difficult to set simple rules for the planning and authorisation process. In 2009, the Ministry of the Environment issued a 'Methodological guide to the assessment of the location of wind and photovoltaic power plants in terms of the protection of nature and landscape', which has set out a procedure for the preparation of preventive studies identifying the interests

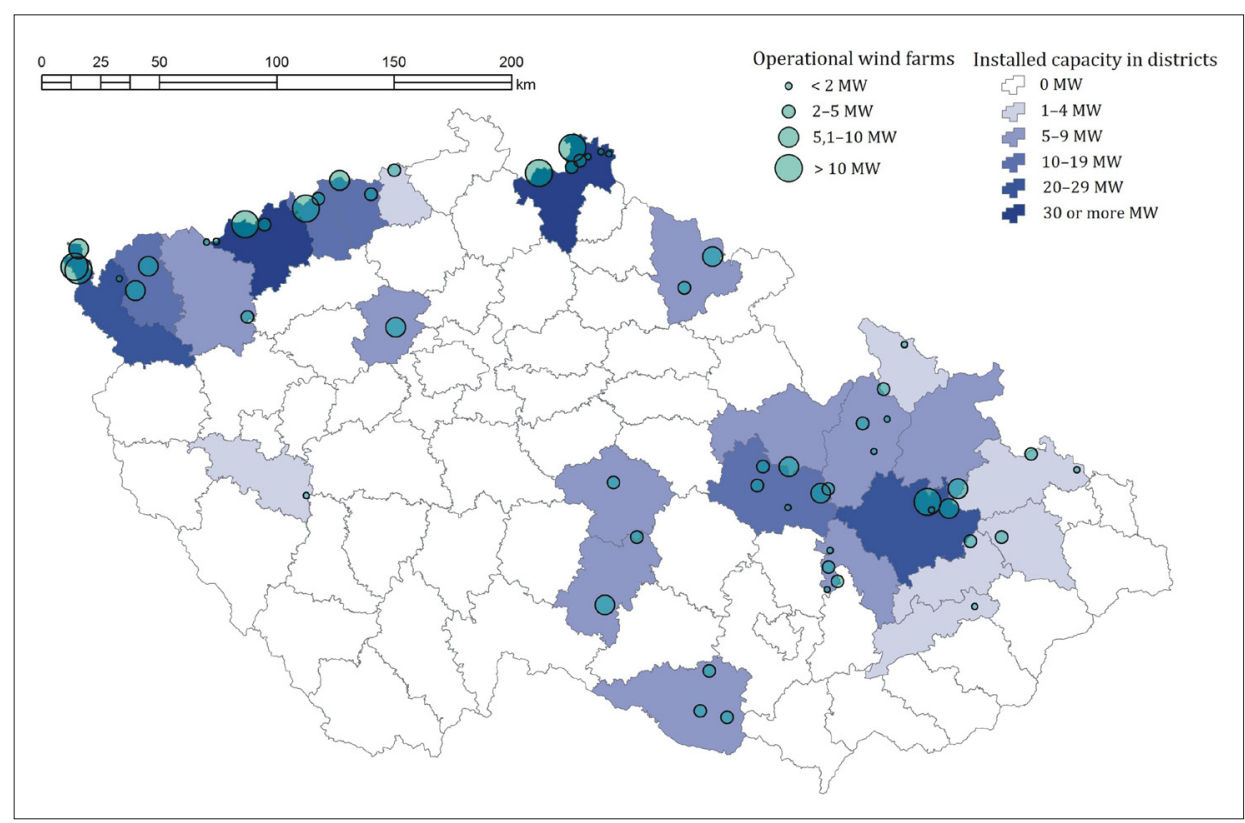

Fig. 1: The location of implemented wind energy projects (circles) and total installed capacity (MW) in districts of the Czech Republic. Source of data: Czech Wind Energy Association (2018); authors' elaboration

of nature and landscape protection at the regional scale, and determining the inappropriateness or potential suitability of power plants in a particular territory. The individual regions vary in their rigidity and approaches, however, and most of them commissioned their own methodological studies as a base for regional territorial planning documentation (see for example, van der Horst, 2009).

Although government subsidies (feed-in-tariffs and green bonuses) for renewables are the same for all regions, differences in the attitudes of regional authorities towards wind energy projects caused (together with other factors) significant spatial differences in the implementation of wind farms (see Fig. 2).

\section{Data and methods}

We hypothesise that socio-political acceptance, the attitudes of regional politicians and officers, the perceptions, motivations and attitudes of mayors of

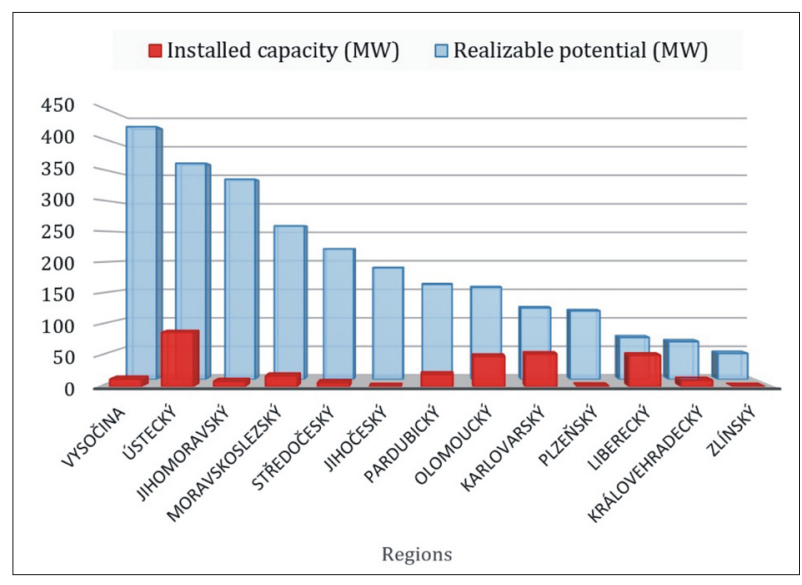

Fig. 2: Regional differences in the deployment of wind energy in the Czech Republic as of 2018

Sources of data: Czech Wind Energy Association (2018); Hanslian et al. (2008); authors' elaboration 
municipalities and residents, and finally the extent of wind energy implementation, can be affected by geographical, environmental and socio-economic factors, and specific regional and local living conditions and experiences. Thus, we carried out statistical tests of the relationships between the level of implementation of wind energy projects and selected area indicators.

As the spatial level of analysis, we have chosen districts (Local Administrative Unit - LAU1) ${ }^{2}$ for which proper statistical data are available and, at the same time, they exhibit a high degree of variance in terms of the realisable potential and installed capacity of wind energy. We used the registry of the Czech Wind Energy Association (CWEA, 2018) as the source of implemented projects, counting the installed capacity of wind energy for each district.

Then we used the study of the Institute of Atmospheric Physics, Czech Academy of Sciences (Hanslian et al., 2008), which assessed the technical potential of wind energy and (considering the environmental, infrastructural and other limitations and constraints) calculated a realisable potential of wind energy for all Czech regions and districts (see Fig. 3). Based on these data, we were able to calculate the degree of utilisation of the realisable potential for districts (Fig. 4).

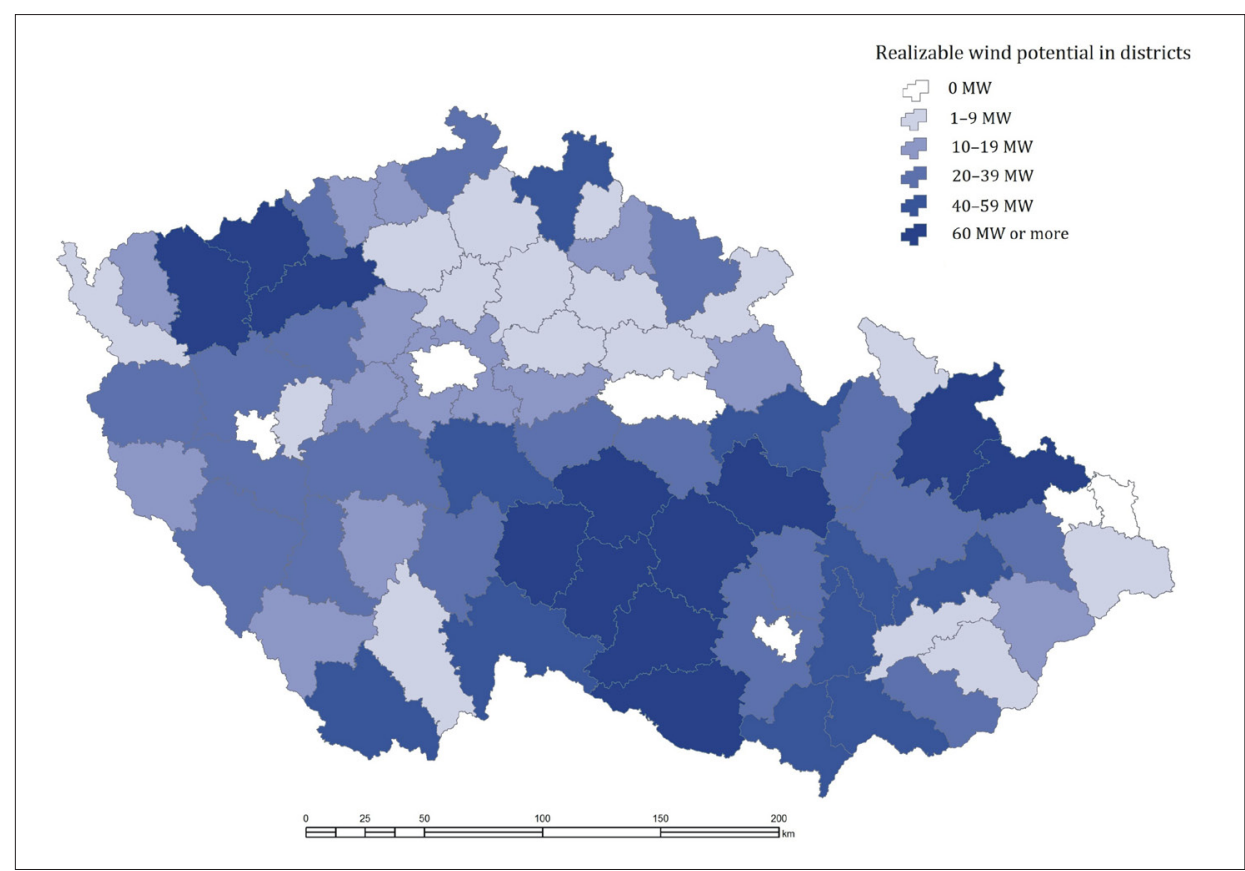

Fig. 3: Regional differences in the realisable wind potential. Source of data: Hanslian et al. (2008); authors' elaboration

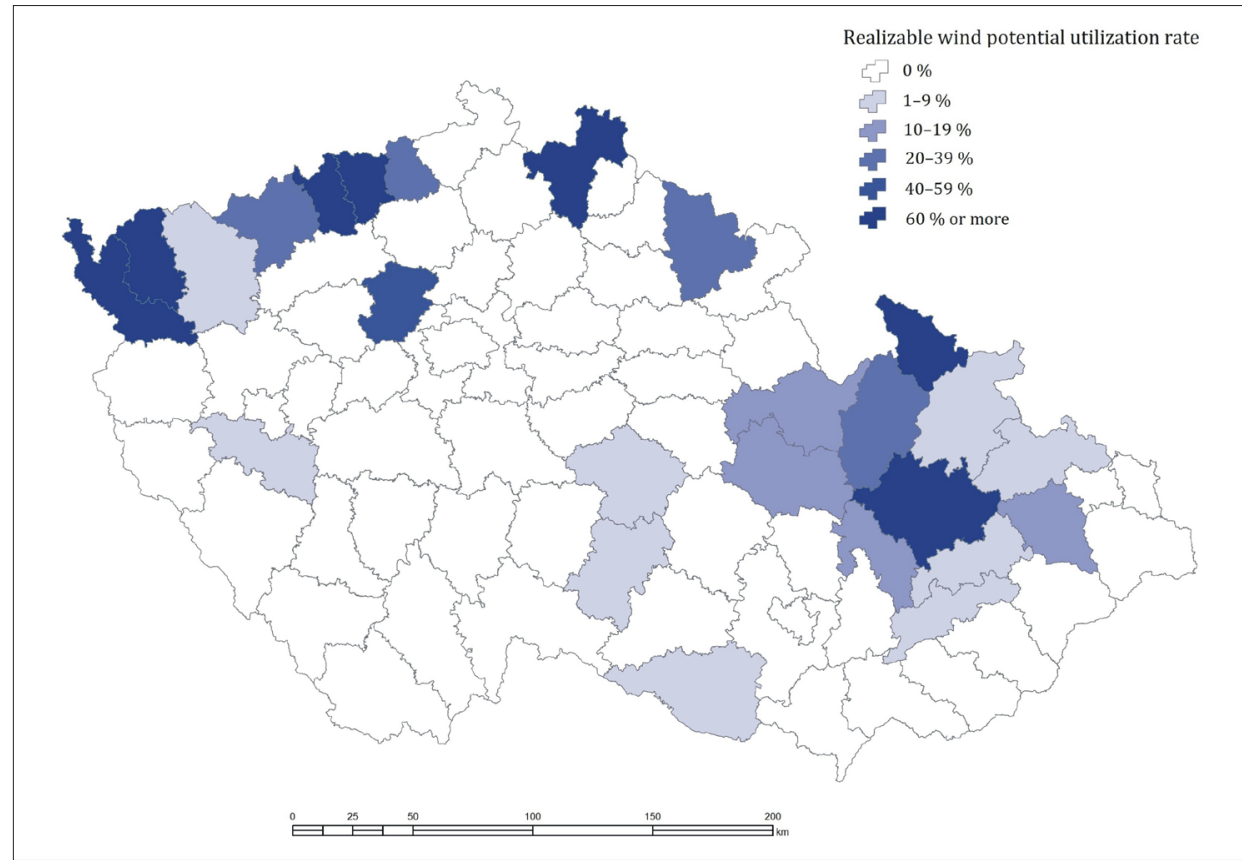

Fig. 4: Regional differences in the utilisation rate of the realisable wind potential as of 2018 Source of data: Hanslian et al. (2008); authors' elaboration

\footnotetext{
${ }^{2}$ There are 76 districts in the Czech Republic, the capital city of Prague does not belong to any of them. The area of districts ranges between 230 and $1,946 \mathrm{~km}^{2}$ (the mean value is $1,031 \mathrm{~km}^{2}$ ).
} 
While some districts (especially in Northern Bohemia and Northern Moravia and Silesia on the borders with Germany and Poland) have already achieved a high degree of utilisation of estimated realisable potential (60\% or more), others that have a high potential (particularly in the Southern part of the country, including Vysočina Region, South-Moravian and South-Bohemian Regions) do not use this potential almost at all.

\begin{tabular}{|c|c|}
\hline Variable & Measure \\
\hline \multicolumn{2}{|l|}{ Geography } \\
\hline Wind resources & Realisable potential of wind energy (MW) \\
\hline Area & Total area $\left(\mathrm{km}^{2}\right)$ \\
\hline Borderland & District is located on the country's border (yes = 1/no = 0) \\
\hline Agricultural land & Share of agricultural land on total area (\%) \\
\hline Forests & Share of forests on total area $(\%)$ \\
\hline Landscape protected areas & Share of protected landscape areas on total area (\%) \\
\hline National parks & Share of national parks on total area (\%) \\
\hline \multicolumn{2}{|l|}{ Environmental deprivation } \\
\hline Air pollutant emissions I & Concentration of $\mathrm{SO}_{2}$ emissions ( $\mathrm{SO} 2$ tones $/ \mathrm{km}^{2}$ ) \\
\hline Air pollutant emissions II & Concentration of $\mathrm{NO}_{\mathrm{x}}$ emissions ( $\mathrm{NOx}$ tones $/ \mathrm{km}^{2}$ ) \\
\hline Air pollutant emissions III & Concentration of $\mathrm{CO}$ emissions ( $\mathrm{CO}$ tones $/ \mathrm{km}^{2}$ ) \\
\hline Coal mining & Active coal mining in district (yes $=1 /$ no $=0$ ) \\
\hline Surface coal mining & Extensive surface coal mining in district $($ yes $=1 /$ no $=0$ ) \\
\hline Coal power plants & Installed capacity of coal power plants in district (MW) \\
\hline \multicolumn{2}{|l|}{ Population and health } \\
\hline Population density & Population per $\mathrm{km}^{2}$ \\
\hline Population increase & Annual population natural increase per 1,000 population \\
\hline Net migration & Number of immigrants less number of emigrants \\
\hline Urbanisation rate & Share of urban population (\%) \\
\hline Ageing index & Number of persons older 60 years or over per 100 persons under age 15 \\
\hline Life expectancy & Male life expectancy at birth (years) \\
\hline Respiratory diseases & Deaths per 100,000 population of respiratory diseases \\
\hline Infant mortality & Infant mortality (\%o) \\
\hline Abortion rate & Abortions per 1,000 population \\
\hline Congenital anomalies & Congenital malformation per 10,000 live births \\
\hline \multicolumn{2}{|l|}{ Economy and labour market } \\
\hline Structural depression & Classified as structurally depressed region $(2007-2013)($ yes $=1 /$ no $=0)$ \\
\hline Unemployment & Unemployment rate $(\%)$ \\
\hline Business activity & Total business units registered per 1,000 population \\
\hline Job vacancies & Job applicants per vacancies \\
\hline Tourism potential & Number of overnight stays in tourist accommodation (2006) \\
\hline \multicolumn{2}{|l|}{ Social capital \& cohesion } \\
\hline Education level & Persons with basic or no formal education (\%) \\
\hline Proportion of natives & People with permanent living at the place of their birth (\%) \\
\hline Ethnic minorities & Number of Roma ethnic people per 1,000 population \\
\hline Homelessness & Number of homeless people per 1,000 population \\
\hline Crime rate & Ascertained offences per 1,000 population \\
\hline Internet availability & Percentage of inhabited flats with PC/internet connection \\
\hline Political involvement & Turnout in regional elections in $2012(\%)$ \\
\hline Green party votes & Share of people voting for Green Party in regional elections $(\%)$ \\
\hline
\end{tabular}

Tab. 2: List of variables included in statistical analysis (Notes: i) The categorisation of variables is only indicative as some variables may belong to several categories; ii) Data are relevant for 2011 unless otherwise indicated) Sources of data: Czech Statistical Office (2011); Ministry of Agriculture (2011); Public Register of Land (pLPIS); State Administration of Land Surveying and Cadastre (2011); Share of forests in districts in the CR; Government of the Czech Republic (2006); Government decision No. 560/2006, on the Definition of regions with concentrated state support for 2007-2013; Vystoupil et al. (2006) 
Subsequently, we created a database of selected variables representing the most relevant geographical characteristics of districts, environmental deprivation indicators, population vital and health statistics, local economy and labour market data, and social capital and social cohesion indicators (see Tab. 2). The selection of indicators was determined by the availability of statistical data at the spatial level of districts in the Czech Republic.

Statistical model testing of the relationships was then carried out: the installed capacity of wind energy within districts was the dependent variable, and the above-listed indicators served as independent variables. We also tested if there is a correlation between those indicators and estimated realisable potential of wind energy to reveal possible multiple-correlation (with both the realisable potential and installed capacity). Statistical procedures were carried out using the SPSS program version 24 , with bi-variate cross-correlation analyses of all independent variables against values of the realisable potential and the installed capacity. The strength of association and statistical significance was tested using Pearson's $\mathrm{r}$ correlation coefficient, and examining the p-value for each pair of variables. Basic results of the bi-variate correlation analyses were published in the form of a short working paper in the Czech language (Frantál and Nováková, 2017).

In addition, we carried out Analysis of Variance (ANOVA) procedures for different groups of districts, as well as estimating multiple linear regression models that included only those selected variables that showed stronger correlations with the installed wind capacity. Considering the exploratory nature of this case study, we put less emphasis on the complexity of the analysis (e.g. in not using any structural modelling, as in some of the previous studies) and more emphasis on the interpretation of findings that were the most statistically significant.

\section{Results and discussion}

First, we examined how much the regional development of wind energy in the Czech Republic is determined by the available wind resources. The correlation between realisable potential of districts and their installed capacity is $\mathrm{r}=0.42$ $(p<0.01)$. In other words, the linear regression model showed that wind energy potential accounts for only $18 \%$ of the variance in the installed capacity of districts; hence, there must be other important factors that affect the differences. We have found statistically significant correlations with the installed capacity of wind energy for 16 indicators, of which only two (education level and unemployment rate) correlate also with the realisable potential (see Tab. 3).

The analysis shows that the estimated realisable potential of wind energy correlates positively with total area and negatively with population density. This seems to be logical and these variables were taken into account by Hanslian et al. (2008) as constraints in the calculation of the realisable potential from a technical potential. But, surprisingly, neither land area nor population density correlate with the installed capacity. This finding is in contradiction to most existing studies (e.g. Goetzke and Rave, 2016; Lauf et al., 2018), which confirmed land area and population density (together with wind potential) best predict the installed capacity. Significant correlations have not been found between installed capacity and the intensity of landscape protection and the use of land in the area (the share of nature and landscape protected areas, forests and agricultural land in

\begin{tabular}{lcc}
\hline \multirow{2}{*}{ Independent variables $^{1}$} & \multicolumn{2}{c}{ The values of correlation $^{2}$} \\
\cline { 2 - 3 } Surface coal mining & with installed capacity & with realisable potential \\
Coal power plants & $0.510^{* *}$ & $\mathrm{n} / \mathrm{s}$ \\
Coal mining & $0.468^{* *}$ & $\mathrm{n} / \mathrm{s}$ \\
Urbanisation rate & $0.381^{* *}$ & $\mathrm{n} / \mathrm{s}$ \\
Green party votes & $0.363^{* *}$ & $\mathrm{n} / \mathrm{s}$ \\
Structural depression & $0.357^{* *}$ & $\mathrm{n} / \mathrm{s}$ \\
Abortion rate & $0.317^{* *}$ & $\mathrm{n} / \mathrm{s}$ \\
Infant mortality & $0.308^{* *}$ & $\mathrm{n} / \mathrm{s}$ \\
Ethnic minorities & $0.303^{* *}$ & $\mathrm{n} / \mathrm{s}$ \\
Education level & $0.296^{* *}$ & $\mathrm{n} / \mathrm{s}$ \\
Unemployment rate & $0.286^{*}$ & $0.354^{* *}$ \\
Life expectancy & $0.265^{*}$ & $0.386^{* *}$ \\
SO ${ }_{2}$ emissions & $-0.260^{*}$ & $\mathrm{n} / \mathrm{s}$ \\
NO ${ }_{\mathrm{x}}$ emissions & $0.260^{*}$ & $\mathrm{n} / \mathrm{s}$ \\
Borderland area & $0.256^{*}$ & $\mathrm{n} / \mathrm{s}$ \\
Political involvement & $0.250^{*}$ & $\mathrm{n} / \mathrm{s}$ \\
Area & $-0.231^{*}$ & $\mathrm{n} / \mathrm{s}$ \\
Population density & $\mathrm{n} / \mathrm{s}$ & $0.437^{* *}$ \\
\hline
\end{tabular}

Tab. 3: Relationships between district characteristics and the installed capacity and realisable potential of wind energy (Notes: 1) Independent variables are listed according to their descending correlation r-value; 2) correlations are significant at the levels of **0.01; *0.05; $\mathrm{n} / \mathrm{s}=$ non-significant correlation

Sources of data: see Table 2; calculations by authors 
the total area of districts). This result can be affected by a generally very low rate of utilisation of the potential and suitable land availability in most Czech regions, however, compared to countries such as Germany or Denmark, where there is already almost no space for new onshore wind farms in some regions (see e.g. Roth et al., 2018).

The strongest correlations were found between the installed capacity of wind energy and the presence of coal mining and the installed capacity of coal-fired power plants within the district. Table 4 shows the significant differences between districts with and without coal mining in the use of wind energy. The districts do not differ significantly in average realisable wind potential, but coal mining districts have an average utilisation rate of the potential of over $40 \%$, compared to less than $10 \%$ in non-mining districts.

Most of the other variables which show significant correlations with the installed capacity of wind energy, at the same time correlate with the presence of coal mining and coal power plants. Overall, this means that the coal energy industry is linked to air pollution, structural depression, higher unemployment, and worse health indicators (lower life expectancy, higher infant mortality). A higher proportion of uneducated people and ethnic minorities in districts affected by coal industries suggest that coal energy is environmentally unjust (cf. Frantál and Nováková, 2014).

To determine the relative strength of the effects of individual variables on installed wind energy capacity, we carried out multiple regression analyses. Since there are strong bi-variate correlations between the presence of coal mining and coal power plants in the district and the structural depression, socio-economic and health indicators, which result in multi-collinearity of the independent variables in the analysis, the final model included only four independent continuous variables that do not significantly correlate with each other (see Tab. 5). This can be regarded as a first level attempt to control for interaction effects. Regarding relative influence, the strongest predictor is the realisable potential (standardised Beta coefficient $=0.41$ ), followed by the votes for the Green Party in regional elections, the installed capacity of coalfired power plants, and the rate of urbanisation. These four independent variables explained $46 \%$ of the variance of the installed wind capacity, indicating that there are other significant variables that have not been included in our analysis. We assume that political-institutional factors at the regional level (e.g. attitudes of regional authorities) will be particularly important, as confirmed by previous studies (Frantál and Kunc, 2010).

The confirmed relationship between the presence of coal energy industries and installed wind energy capacity may indicate several things. First, we could assume that in environmentally deprived areas, wind energy is being adopted more positively as an alternative source to fossil fuels. This is in line with the findings of Balta-Ozkan et al. (2016), who found that smaller households in highly polluted areas in the UK are early adopters of PV installations. Van der Horst (2007) mentions other case studies showing that the existence of heavy industry and large stacks in the area appears to make residents more likely to support wind farms as an improvement of the image of the area. Another reason can be that people living in coal mining landscapes are aware that the lifestyles we lead have attendant costs and that electricity does not come 'out of the switch' but from the earth, it has to be produced somewhere, transported, stored, etc. (cf. Pasqualetti, 2000; van der Horst, 2007).

\begin{tabular}{lcccc}
\hline \multirow{2}{*}{ Indicators } & \multicolumn{2}{c}{ District category ${ }^{1}$} & \multicolumn{2}{c}{ Statistics } \\
\cline { 2 - 5 } & Non-mining & Mining & F test & Eta $^{2}$ \\
\hline Total realisable potential of wind energy [MW] & 2,285 & 249 & - & - \\
Average realisable potential of wind energy [MW] & 32.7 & 41.5 & 0.298 & 0.063 \\
Total installed capacity [MW] & 208 & 103 & - & - \\
Average installed capacity [MW] & 2.9 & 17.2 & 12.576 & $0.391^{*}$ \\
Utilisation of the realisable potential [\%] & 9 & 41 & - & - \\
\hline
\end{tabular}

Tab. 4: Differences in the utilisation of wind energy potential in coal mining and non-mining districts (Notes: 1) The mining district category includes six districts where coal mining is still active; the non-mining category includes all other districts of the Czech Republic; 2) Measures of association (Eta) are significant at *p $<0.001$ ) Sources of data: Hanslian et al. (2008); Czech Wind Energy Association (2018); authors' calculations

\begin{tabular}{lcccc}
\hline \multicolumn{1}{c}{ Predictors } & \multicolumn{2}{c}{ Unstandardised Coefficients } & $\begin{array}{c}\text { Standardised } \\
\text { Coefficients }\end{array}$ & Sig. \\
\cline { 2 - 4 } & B & S.E. & Beta & -3.997 \\
\hline Constant ) & -12.985 & 3.248 & 0.000 \\
Realisable wind potential (MW) & 0.109 & 0.025 & 0.408 & 0.000 \\
Capacity of coal power plants (MW) & 0.007 & 0.003 & 0.233 & 2.344 \\
Share of urban population (\%) & 1.610 & 0.765 & 0.214 & 0.022 \\
Green party votes (\%) & 2.586 & 0.911 & 0.272 & 0.039 \\
\hline
\end{tabular}

$\mathrm{R}^{2}=0.46$; Sig. $=0.001$

Dependent variable: Installed capacity of wind energy (MW)

Tab. 5: Regression model for installed wind energy capacity

Source: authors' calculations 
Van der Horst (2007, p. 2709), however, also points out that the lack of organised opposition to wind farms does not directly mean that people are actually in favour of them. The (passive) acceptance can be just an indicator of low political efficacy (due to lower education and lack of social capital) and resignation, which is often a characteristic phenomenon in environmentally deprived areas (Frantál, 2016). On the contrary, lower environmental and health deprivation may be correlated with higher political involvement and higher local opposition to new energy projects (van der Horst and Toke, 2010).

On the other hand, we found a positive correlation between installed wind capacity and votes in regional elections for the Green Party, which is the only political party in the Czech Republic which supports the development of renewable energy resources in the long term. The same relationship was confirmed by data from Germany (Goetzke and Rave, 2016). As in Germany, there are, however, regional differences in the effect of this variable in the Czech Republic. The correlation between wind energy and Green Party votes is quite strong and significant $(r=0.674$, $\mathrm{p}<0.05$ ) in coal mining districts, but it is not significant in districts without coal mining. The high support for the 'Greens' may therefore be linked primarily to their opposition to possible change to the territorial ecological limits of coal mining in the North Bohemian coal basin (see, for example, Frantál, 2016) and not directly to their support for renewable energy.

The higher adoption of wind energy in regions with coal-fired power plants is to a certain extent in contrast to the lower acceptance of wind energy in Czech regions where nuclear power plants are located (see Frantál and Malý, 2017). Perhaps, a general familiarisation with the risks related to nuclear power, together with significant economic impacts of nuclear power plants in hosting regions (providing jobs, property tax revenues, investments in local infrastructure, etc.), could make municipalities no longer motivated to support other (wind) energy projects in their backyards (ibid.). This is actually in line with the situation in Austria, Germany or China, where people are willing to pay for and support wind energy to prevent a nuclear power plant from being constructed in their regions (Frantál and Kučera, 2008, Sun et al., 2016, Yamane et al., 2011). Another example of the negative correlation between developments of different energy sources was provided by Xia and Song (2018) from China, where an increase in the installed capacity of hydropower plants in an area led to a decrease of installed wind power capacity. The higher adoption of wind energy in coal mining regions is probably affected also by the fact that Czech coal power plants do not provide (in comparison with nuclear power plants and wind farms) local communities with direct financial benefits and investments.

The significant correlation between the installed capacity of wind energy and the rate of urbanisation in Czech districts supports the hypothesis that wind farms are more likely to be implemented in areas with a lower concentration of second home or holiday home owners escaping from a city for unspoiled landscapes and the 'rural idyll' (Cowell et al., 2011; Janhunen et al., 2014; van der Horst and Toke, 2010). An interesting finding from our analysis is the small but significant correlation between the higher installed capacity of wind energy and the location of a district in borderland areas. While these districts do not significantly differ in average wind potential (which is $31 \mathrm{MW}$ in inner districts and $37 \mathrm{MW}$ in borderland districts), they do significantly differ in the average installed capacity (1.8 MW in inner districts and 6.8 MW in borderland districts: $\mathrm{F}=4.951$, Eta $=0.25$, $\mathrm{p}<0.05$ ). There may be different reasons for this pattern. Since all coal mining districts are in the borderland areas, the factor of environmental deprivation is likely to intervene here. It is also visible from the map (Figure 1) that larger wind farms are mainly in areas where large wind farms are also located on the other side of the border, i.e. in Saxony (Germany), Lower and Upper Silesia (Poland) and Lower Austria (Austria). Czech people living in these border regions were more likely to see and experience wind turbines personally, so that they could be more familiar with them. Another possible factor is that municipalities on the borders generally have fewer neighbouring municipalities (within a country) that may be in opposition to projects and may intervene in decision-making processes. These hypotheses, however, deserve further verification through research at the local level and with respect to the emerging field of borderlands research.

\section{Conclusions}

The aim of this exploratory study was to provide new empirical evidence to respond to the research question: To what extent are regional differences in wind energy development related to specific geographical, environmental and socio-economic factors. The analysis of statistical data for districts revealed that the existing spatial differences in the deployment of wind energy in the Czech Republic cannot be explained by the differences in territory area, population density or the intensity of land use and protection (measured as the share of nature and landscape protected areas, forests and agricultural land). This is in contradiction to previous studies from the USA, Germany and Sweden (Staid and Guikema, 2013; Goetzke and Rave, 2016; Ek et al., 2013).

The statistically higher installed capacity of wind energy in the Czech Republic is found in more urbanised areas, in those areas with active coal mining and with a high concentration of coal-fired power plants, which are also characterised by higher emissions and the lower status of the health of the local population, as well as by structural economic depression with high rates of long-term unemployment, and higher concentrations of people with basic or no formal education and ethnic minorities. The coalmining districts have levels of more than a four times higher rate of utilisation of their realisable wind energy potential than other districts ( $40 \%$ vs. $9 \%$ ), even though they do not significantly differ in the average realisable wind potential, which is related to land area and population density.

The results suggest that in coal-mining and environmentally deprived areas, renewable energy is more positively perceived and adopted as an alternative source of energy to 'dirty' coal. Higher levels of acceptance may be due to the fact that in environmentally deprived areas economic motivations (e.g. financial compensation for local communities) can have greater effects on local acceptance, while public opposition is less efficient due to lower efficacy and involvement in political matters (cf. van der Horst, 2007; Frantál, 2016).

Nevertheless, the modest coefficient of multiple determination ( $\mathrm{R} 2=46 \%$ ) for our final multiple regression model (with independent variables: wind energy potential of a district; urbanisation rate; installed capacity of coalfired-power plants; and Green Party votes) calls for further 
research that will take into account other variables and focus on more spatial levels (i.e. the level of both the municipalities and regions). As Goetzke and Rave (2016) emphasised, it also seems important for future research to distinguish between different types of wind energy projects, mainly in terms of ownership and citizen participation but also spatial scale (size).

With regard to policy and practice, the results of our study suggest that the spatial targetting of new energy projects (not only wind farms but also other energy facilities) towards environmentally and economically depressed regions will be an easier way for planners and developers to reduce the risk of vocal local public opposition. The concentration of power plants and other polluting and risky facilities (such as refineries, incinerator plants or nuclear waste disposal sites) to the landscapes "sacrificed for the state's energy security", raises questions of environmental and/or energy injustice, and the uneven spatial and social distribution of benefits and costs of energy production (see for example: Sovacool and Dworkin, 2015; Sovacool et al., 2017). It has been suggested that renewable energy (with communitybased distributed generation) offers unique opportunities for addressing energy justice issues, such as access and energy security, with less environmental impact (Outka, 2012). It does seem, however, that new energy systems (which should replace fossil resources) as they are currently being designed share some characteristics with their predecessors (such as spatial concentration, procedural injustice and lack of trust) - and may reproduce old patterns of environmental injustice (Ottinger, 2013).

Small-scale deployments constitute an easier way to reduce both landscape impacts and spatial concentration, being more acceptable for both residents and tourists (e.g. Frantál and Kunc, 2011). The re-territorialisation process ('one village - one wind turbine,') taking place in Belgium and some other countries is a striking example of the socalled smart practice for siting renewable energy projects (see Frantál et al., 2018). Small-scale projects, however, have limited and often insufficient outputs to achieve longerterm national targets for emission reduction. Therefore, the process of de-concentration or re-territorialisation of energy production requires the involvement of all to share the spatial cost of energy. For the time being, however, this is opposed by many politicians and ordinary people (and not only in the Czech Republic) who strictly claim "no wind turbines in our region!".

\section{Acknowledgement}

The paper is an output from the project "Exploring social-spatial diffusion of renewable energy projects in the Czech Republic: lessons for adaptive governance of energy transition" (No. 16-04483S), funded by the Czech Science Foundation.

\section{References:}

AITKEN, M. (2010): Why we still don't understand the social aspects of wind power: A critique of key assumptions within the literature. Energy Policy, 38(4): 1834-1841.

BALTA-OZKAN, N., LE GALLO, J. (2018): Spatial variation in energy attitudes and perceptions: Evidence from Europe. Renewable and Sustainable Energy Reviews, 81: 2160-2180.
BALTA-OZKAN, N., WATSON, T., MOCCA, E. (2015): Spatially uneven development and low carbon transitions: Insights from urban and regional planning. Energy Policy, 85: 500-510.

BALTA-OZKAN, N., YILDIRIM, J., CONNOR, P. M. (2015): Regional distribution of photovoltaic deployment in the UK and its determinants: A spatial econometric approach. Energy Economics, 51: 417-429.

BECKMAN, J., XIARCHOS, I. M. (2013): Why are Californian farmers adopting more (and larger) renewable energy operations? Renewable Energy 55: 322-330.

BOLLINGER, B., GILLINGHAM, K. (2012): Peer effects in the diffusion of solar photovoltaic panels. Marketing Science, 31(6): 900-912.

BOYD, A. D., PAVEGLIO, T. B. (2015): "Placing" Energy Development in a Local Context: Exploring the Origins of Rural Community Perspectives. Journal of Rural and Community Development, 10(2): 1-20.

BREUKERS, S., WOLSINK, M. (2007): Wind power implementation in changing institutional landscapes: An international comparison. Energy policy, 35(5): 2737-2750.

BRIDGE, G., BOUZAROVSKI, S., BRADSHAW, M., EYRE, N. (2013): Geographies of energy transition: Space, place and the low-carbon economy. Energy policy, 53: $331-340$.

BUEN, J. (2006): Danish and Norwegian wind industry: The relationship between policy instruments, innovation and diffusion. Energy policy, 34(18): 3887-3897.

CALVERT, K. (2016). From 'energy geography' to 'energy geographies' Perspectives on a fertile academic borderland. Progress in Human Geography, 40(1): 105-125.

CHALUPA, Š., HANSLIAN, D. (2015): Analýza větrné energetiky v ČR. Praha, Komora obnovitelných zdrojů energie [online]. Available at: http://www.csve.cz/img/ wysiwyg/file/KomoraOZE_analyza-potencial-OZE_dilciVTE_log.pdf

COWELL, R., BRISTOW, G., MUNDAY, M. (2011): Acceptance, acceptability and environmental justice: the role of community benefits in wind energy development. Journal of Environmental Planning and Management, 54(4): 539-557.

CZECH STATISTICAL OFFICE (2011): Data from Population Census 2011 [online] Available at: https:// www.czso.cz/csu/sldb

CZECH WIND ENERGY ASSOCIATION (CWEA) (2018): Current installation in wind [online]. Available at: http:// www.csve.cz/clanky/aktualni-instalace-vte-cr/120

DALLA VALLE, A., FURLAN, C. (2011): Forecasting accuracy of wind power technology diffusion models across countries. International Journal of Forecasting, 27(2): 592-601.

DAVIES, S. W., DIAZ-RAINEY, I. (2011): The patterns of induced diffusion: Evidence from the international diffusion of wind energy. Technological forecasting and social change, 78(7): 1227-1241.

DHARSHING, S. (2017): Household dynamics of technology adoption: A spatial econometric analysis of residential solar photovoltaic (PV) systems in Germany. Energy research \& social science, 23: 113-124. 
DIEBOLT, C., MISHRA, T., PARHI, M. (2016): Dynamics of Distribution and Diffusion of New Technology: A Contribution to the Historical, Economic and Social Route of a Developing Economy. Cham, Springer.

EK, K., PERSSON, L., JOHANSSON, M., WALDO, A. (2013): Location of Swedish wind power-Random or not? A quantitative analysis of differences in installed wind power capacity across Swedish municipalities. Energy Policy, 58: 135-141.

ENERGY REGULATORY OFFICE (ERO) (2018): Roční zpráva o provozu ES ČR 2017 [online]. Available at: https://www.eru.cz/zpravy-o-provozu-elektrizacnisoustavy\#2018

FAST, S., MABEE, W. (2015): Place-making and trustbuilding: The influence of policy on host community responses to wind farms. Energy Policy, 81: 27-37.

FERGUSON-MARTIN, C. J., HILL, S. D. (2011): Accounting for variation in wind deployment between Canadian provinces. Energy Policy, 39(3): 1647-1658.

FIRESTONE, J., BATES, A., KNAPP, L. A. (2015): See me, Feel me, Touch me, Heal me: Wind turbines, culture, landscapes, and sound impressions. Land Use Policy, 46: $241-249$

FOURNIS, Y., FORTIN, M. J. (2017): From social 'acceptance' to social 'acceptability' of wind energy projects: towards a territorial perspective. Journal of environmental planning and management, 60(1): 1-21.

FRANTÁL, B. (2016): Living on coal: Mined-out identity, community displacement and forming of anti-coal resistance in the Most region, Czech Republic. Resources Policy, 49 (September): 385-393.

FRANTÁL, B., KUČERA, P. (2009): Impacts of the operation of wind turbines as perceived by residents in concerned areas. Moravian Geographical Reports, 17(2): 34-45.

FRANTÁL, B., KUNC, J. (2010): Factors of the uneven regional development of wind energy projects (a case of the Czech Republic). Geografický Časopis/Geographical Journal (Slovak), 62(3): 183-201.

FRANTÁL, B., KUNC, J. (2011): Wind turbines in tourism landscapes: Czech experience. Annals of tourism research, 38(2): 499-519.

FRANTÁL, B., NOVÁKOVÁ, E. (2014): A Curse of Coal? Exploring Unintended Regional Consequences of Coal Energy in the Czech Republic. Moravian Geographical Report, 22(2): 55-65.

FRANTÁL， B., NOVÁKOVÁ, E. (2017). Regionální diferenciace rozvoje větrné energetiky. Energie 21(4): 18-20.

FRANTÁL, B., MALÝ, J. (2017): Close or renew? Factors affecting local community support for rebuilding nuclear power plants in the Czech Republic. Energy Policy, 104(5): 134-143.

FRANTÁL, B., PASQUALETTI, M., VAN DER HORST, D. (2014): New trends and challenges for energy geographies: Introduction to the Special Issue. Moravian Geographical Reports, 22(2): 2-6.

FRANTÁL, B., VAN DER HORST, D., KUNC, J., JAŇUROVÁ, M. (2017): Landscape disruption or just a lack of economic benefits? Exploring factors behind the negative perceptions of wind turbines. Tájökológiai
Lapok (Hungarian Journal of Landscape Ecology), 13(2): 139-147.

FRANTÁL, B., VAN DER HORST, D., MARTINÁT, S., SCHMITZ, S., TESCHNER, N., SILVA, L., GOLOBIC, M., ROTH, M. (2018). Spatial targeting, synergies and scale: Exploring the criteria of smart practices for siting renewable energy projects. Energy Policy, 120: 85-93.

GOETZKE, F., RAVE, T. (2016): Exploring heterogeneous growth of wind energy across Germany. Utilities Policy, 41: 193-205.

GRAZIANO, M., GILLINGHAM, K. (2014): Spatial patterns of solar photovoltaic system adoption: the influence of neighbours and the built environment. Journal of Economic Geography, 15(4): 815-839.

HÄGERSTRAND, T. (1968): Innovation Diffusion as a Spatial Process. Chicago, University of Chicago Press.

HANSEN, T., COENEN, L. (2015). The geography of sustainability transitions: Review, synthesis and reflections on an emergent research field. Environmental innovation and societal transitions, 17: 92-109.

HANSLIAN, D. et al. (2008): Odhad realizovatelného potenciálu větrné energie na území ČR. Praha, Ústav fyziky atmosféry AV ČR.

HEISKANEN, E., MATSCHOSS, K. (2017): Understanding the uneven diffusion of building-scale renewable energy systems: A review of household, local and country level factors in diverse European countries. Renewable and Sustainable Energy Reviews, 75: 580-591.

HOEFNAGELS, E. T. A., JUNGINGER, H. M., PANZER, C., RESCH, G., HELD, A. (2011): Long Term Potentials and Costs of RES - Part I: Potentials, Diffusion and Technological learning. Utrecht, Utrecht University.

HOWELLS, J., BESSANT, J. (2012): Introduction: innovation and economic geography: a review and analysis. Journal of economic geography, 12(5): 929-942.

JANHUNEN, S., HUJALA, M., PÄTÄRI, S. (2014): Owners of second homes, locals and their attitudes towards future rural wind farm. Energy Policy, 73: 450-460.

JOBERT, A., LABORGNE, P., MIMLER, S. (2007): Local acceptance of wind energy: Factors of success identified in French and German case studies. Energy policy, 35(5): 2751-2760.

LANGER, K., DECKER, T., ROOSEN, J., MENRAD, K. (2016): A qualitative analysis to understand the acceptance of wind energy in Bavaria. Renewable and Sustainable Energy Reviews, 64: 248-259.

LAUF, T., EK, K., GAWEL, E., LEHMANN, P., SÖDERHOLM, P. (2018): The Regional Heterogeneity of Wind Power Deployment: An Empirical Investigation of Land-use Policies in Germany and Sweden. UFZ Discussion Papers, 1: 1-30.

LUPP, G., BASTIAN, O., SYRBE, R. U., STEINHÄUßER, R. (2014): Perceptions of energy crop production by lay people and farmers using the ecosystem services approach. Moravian Geographical Reports, 22(2): 15-25.

MANN, D., LANT, C., SCHOOF, J. (2012): Using map algebra to explain and project spatial patterns of wind energy development in Iowa. Applied Geography, 34: 219-229. 
MARTINAT, S., NAVRATIL, J., TROJAN, J., FRANTAL, B., KLUSACEK, P., PASQUALETTI, M. J. (2017): Interpreting regional and local diversities of the social acceptance of agricultural $\mathrm{AD}$ plants in the rural space of the Moravian-Silesian Region (Czech Republic). Rendiconti Lincei, 28(3): 535-548.

MARTINOVSKÝ, P., MAREŠ, M. (2012): Political support for nuclear power in Central Europe. International Journal of Nuclear Governance, Economy and Ecology, 3(4): 338-359.

MBZIBAIN, A., HOCKING, T. J., TATE, G., ALI, S. (2013): Renewable enterprises on UK farms: Assessing levels of uptake, motivations and constraints to widespread adoption. Biomass and bioenergy, 49: 28-37.

MINISTRY OF AGRICULTURE (2011): Public Register of Land (pLPIS) [online] Available at: http://eagri.cz/public/ app/lpisext/lpis/verejny2/plpis/

OTTINGER, G. (2013): The winds of change: environmental justice in energy transitions. Science as Culture, 22(2): 222-229.

OUTKA, U. (2012): Environmental justice issues in sustainable development: Environmental justice in the renewable energy transition. Journal of Environmental and Sustainability Law, 19(1): 60.

PALM, J., TENGVARD, M. (2011): Motives for and barriers to household adoption of small-scale production of electricity: examples from Sweden. Sustainability: Science, Practice and Policy, 7(1): 6-15.

PASQUALETTI, M. J., BROWN, M. A. (2014): Ancient discipline, modern concern: Geographers in the field of energy and society. Energy Research \& Social Science, 1: $122-133$.

PEARCE, J.R., RICHARDSON, E.A., MITCHELL, R. J., SHORTT, N. K. (2010): Environmental justice and health: the implications of the socio-spatial distribution of multiple environmental deprivation for health inequalities in the United Kingdom. Transactions of the Institute of British Geographers, 35(4): 522-539.

PETTERSSON, M., EK, K., SÖDERHOLM, K., SÖDERHOLM, P. (2010): Wind power planning and permitting: Comparative perspectives from the Nordic countries. Renewable and Sustainable Energy Reviews, 14(9): 3116-3123.

PIRIA, R., HOCKENOS, P., MÜLLER-KRAENNER, S., ONDRICH, J. (2014): Greening the Heartlands of Coal in Europe. Insights from a Czech-German-Polish Dialogue on Energy Issues. Berlin, Heinrich Böll Stiftung.

RAND, J., HOEN, B. (2017): Thirty years of North American wind energy acceptance research: What have we learned?. Energy research \& social science, 29: $135-148$.

RAO, K. U., KISHORE, V. V. N. (2009): Wind power technology diffusion analysis in selected states of India. Renewable Energy, 34(4): 983-988.

RICHARDSON, E.A., PEARCE, J., MITCHELL, R., SHORTT, N.K. (2013): A regional measure of neighborhood multiple environmental deprivation: Relationships with health and health inequalities. The Professional Geographer, 65(1): 153-170.
ROTH, M., EITER, S., RÖHNER, S., KRUSE, A., SCHMITZ, S., FRANTÁL, B., CENTERI, C., FROLOVA, M., BUCHECKER, M., STOBER, D., KARAN, I., VAN DER HORST, D. [eds.] (2018): Renewable Energy and Landscape Quality. Berlin, Jovis.

SARDIANOU, E., GENOUDI, P. (2013): Which factors affect the willingness of consumers to adopt renewable energies? Renewable energy, 57: 1-4.

SCHAFFER, A. J., BRUN, S. (2015): Beyond the sun socioeconomic drivers of the adoption of small-scale photovoltaic installations in Germany. Energy Research \& Social Science, 10: 220-227.

SOVACOOL, B. K., DWORKIN, M. H. (2015): Energy justice: Conceptual insights and practical applications. Applied Energy, 142: 435-444.

SOVACOOL, B. K., BURKE, M., BAKER, L., KOTIKALAPUDI, C. K., WLOKAS, H. (2017): New frontiers and conceptual frameworks for energy justice. Energy Policy, 105: 677-691.

STAID, A., GUIKEMA, S. D. (2013): Statistical analysis of installed wind capacity in the United States. Energy Policy, 60: 378-385.

SUN, C., ZHU, X., MENG, X. (2016): Post-Fukushima public acceptance on resuming the nuclear power program in China. Renewable and Sustainable Energy Reviews, 62: 685-694.

SUŠKEVIČS, N. B., EITER, S., MARTINAT, S., STOBER, D., VOLLMER, E., DE BOER, C. L., BUCHECKER, M. (2019): Regional variation in public acceptance of wind energy development in Europe: What are the roles of planning procedures and participation? Land use policy, 81: $311-323$.

TATE, G., MBZIBAIN, A., ALI, S. (2012): A comparison of the drivers influencing farmers' adoption of enterprises associated with renewable energy. Energy Policy, 49: 400-409.

TOKE, D., BREUKERS, S., WOLSINK, M. (2008): Wind power deployment outcomes: How can we account for the differences? Renewable and sustainable energy reviews, 12(4): 1129-1147.

TRANTER, R. B., SWINBANK, A., JONES, P. J., BANKS, C. J., SALTER, A. M. (2011): Assessing the potential for the uptake of on-farm anaerobic digestion for energy production in England. Energy Policy, 39(5): 2424-2430.

VAN DER HORST, D. (2009). Spatial planning of wind turbines and the limits of 'objective' science. Moravian Geographical Reports, 17(2): 46-51.

VAN DER HORST, D. (2007): NIMBY or not? Exploring the relevance of location and the politics of voiced opinions in renewable energy siting controversies. Energy policy, 35(5): 2705-2714.

VAN DER HORST, D., TOKE, D. (2010): Exploring the landscape of wind farm developments; local area characteristics and planning process outcomes in rural England. Land Use Policy, 27(2): 214-221.

VYSTOUPIL, J., HOLEŠINSKÁ, A., KUNC, J., MARYÁŠ, J., SEIDENGLANZ, D., ŠAUER, M., TONEV, P., VITURKA, M. (2006): Atlas cestovního ruchu České republiky. Praha, Ministerstvo pro místní rozvoj ČR. 
WOLSINK, M. (2012): Wind Power: Basic Challenge Concerning Social Acceptance. In: Meyers, R. A. [ed.]: Encyclopedia of Sustainability Science and Technology, 17: 12218-12254. New York, Springer.

XIA, F., SONG, F. (2017): The uneven development of wind power in China: Determinants and the role of supporting policies. Energy Economics, 67: 278-286.
YAMANE, F., OHGAKI, H., ASANO, K. (2011): Social factors affecting economic welfare of the residents around nuclear power plants in Japan. Energy Procedia, 9: 619629 .

\section{Please cite this article as:}

FRANTÁL, B., NOVÁKOVÁ, E. (2019): On the spatial differentiation of energy transitions: Exploring determinants of uneven wind energy developments in the Czech Republic. Moravian Geographical Reports, 27(2): 79-91. Doi: 10.2478/mgr-2019-0007. 